\title{
THE IMPACT OF BANKING SECTOR COMPETITION ON BANKS' RISK-TAKING IN TRANSITION ECONOMIES OF CENTRAL AND SOUTH-EASTERN EUROPE
}

Arben Mustafa, Valentin Toçi

\section{Abstract}

This paper uses the Panzar-Rosse H-statistic to provide empirical evidence on the impact of competitive behaviour of banks on risk-taking, using the Fixed Effects Vector Decomposition Method on panel data of banks in 15 Central and South-Eastern Europe countries during the period 1999-2009. The findings suggest that banking sector competition has had a negative impact on banks' risk-taking implying that competition contributed to the improvement of the loan-portfolio quality. However, the results differ significantly when distinguishing between the EU and non-EU countries of the CESEE region. While for the EU countries the relationship between banking sector competition and risk-taking remains negative, this relationship is positive for the non-EU countries of the region, suggesting that an increase of competition in the non-EU countries may be detrimental for the stability of the banking sector in these countries. These results are robust to different model specifications and measures of competition.

Keywords: Banking sector risks, Competition, Central and South-Eastern Europe

JEL Classification: $G 32, D 4, P 2$

\section{INTRODUCTION}

The main challenge for the banking sectors in the Central and South-Eastern Europe countries (CESEE) during the transition process was the management of risks, which became a serious threat to the stability and development of the banking sector. For example, the reasons for the high non-performing loans (NPLs) were multiple, starting from the legacies inherited from the centrally-planned economies, the poor corporate governance of the newly created banks, the weak institutions, and the poor macroeconomic performance. However, the long process of the governments' interventions to clean banks' balance sheets from NPLs, reform of the banking sector by privatizing the state-owned banks and strengthening the financial regulatory and supervisory institutions, led to substantial improvement of loan portfolio quality in the CESEE.
The issue of bank risks is considered as highly important both in the literature and among the regulators and banking professionals, primarily because banks' bankruptcies are expected to be associated
Arben Mustafa, $\mathrm{PhD}$
Assistant Professor
University "Kadri Zeka" Gjilan, Faculty of Economics and CERGE-EI Teaching Career Integration Fellow
E-mail: arben.mustafa@uni-gjilan.net
Valentin Toçi, $\mathrm{PhD}$
Associate Professor
University of Prishtina "Hasan Prishtina", Faculty of
Economics
E-mail: valentintoci@gmail.com 
with much larger negative consequences for the economy compared to other firms. In the literature, theoretical and empirical, considerable attention has been paid to the relationship between competition and the risk-taking behaviour of banks. The literature is inconclusive whether competition leads to a higher, or lower, level of risk-taking by banks. The investigation of the relationship between banking sector competition and risk-taking is particularly important for the CESEE countries, given that banking sector competition evolved substantially when foreign banks started to enter these markets. In addition, competition is expected to increase further as the non-EU countries of the CESSE move towards the EU membership.

Aiming at shedding light to the relationship between banking sector competition and risk-taking in the CESEE, this paper investigates this relationship for a sample of 292 banks in 15 CESEE countries during the period 1999-2009 using bank-level data sourced from the BankScope database. ${ }^{1}$ The novelty of this paper is that as the measure of competition is used the Panzar-Rose $\mathrm{H}$-statistic, for the first time in transition context in CESEE, estimated for each country and for each year. The previous studies have mostly used market concentration indices, such as Lerner Index and Herfindahl-Hirschman Index $(\mathrm{HHI})$, which might not represent adequate measures of competition. The degree of the bank's risk-taking is proxied by loan-loss provisions, which reflects the quality of the bank's loan portfolio. The model controls for the impact of other bank-specific, macroeconomic and institutional variables. Given the potential differences between the non-EU and the EU countries with respect to the banks' behaviour and the operating environment, we also test whether the relationship between banking sector competition and risk-taking in the non-EU countries of the CESEE region is significantly different from that in the EU countries of the region. The estimation is conducted using the Fixed Effects Vector Decomposition Method (FEVDM).

\section{THEORETICAL AND EMPIRICAL BACKGROUND}

The existing literature has paid considerable attention to the relationship between competition and the risktaking behaviour of banks, with the largest part of the literature arguing that competition leads to a higher level of risk-taking by banks. However, there are also

\footnotetext{
1 Countries included in the analysis are: Albania, Bosnia and Herzegovina, Bulgaria, Croatia, Czech Republic, Estonia, Hungary, Latvia, Lithuania, Macedonia, Montenegro, Poland, Romania, Serbia, Slovenia, and Slovakia. Kosovo is not included in the analysis because of missing data series for some of the variables.
}

views that argue for a negative relationship between banking sector competition and risk-taking.

The view that more competition leads to higher risk-taking by banks is mainly based on the "franchise value" or "charter value" hypothesis that derives from market-related (e.g. regulatory measures) and bankrelated (e.g. efficiency of banks) sources (Demsetz, Saidenberg, and Strahan 1996) and (Keeley 1990). According to this hypothesis, with more market power, banks would be inclined to take less risk, since potential bankruptcy would imply giving up the opportunity to earn the profits that could be earned if the bank continued to operate. On the other hand, a higher level of competition may imply a larger number of banks operating in the market, which would seek to maintain/increase their market share by operating at lower interest margins. This might lead to lower profits and consequently make the franchise less valuable. The decrease of the franchise value, in turn, reduces the opportunity cost of the bankruptcy and, as a result, the bank might be willing to take higher levels of risk. The higher level of undertaken risk may then be reflected into a lower quality of the asset portfolio and a lower level of bank capitalization. The franchise value hypothesis is supported also by a number of other authors such as Hellman, Murdock, and Stiglitz (2000) and Repullo (2004) who have claimed that increased competition leads to higher risk-taking by banks.

Another strand of the banking literature investigates the impact of competition on bank risk-taking from the perspective of asymmetric information theories, leading to adverse selection and moral hazard. According to Marquez (2002), as the number of banks increases, each bank has less information about the market participants because of the "information dispersion" among banks. As the number of banks increases, each bank has information on a smaller number of potential borrowers, implying that the bank will not be able to use the information on borrowers' past performance when deciding whether to grant a loan. Consequently, banks can end up granting loans also to bad borrowers. However, this theory does not take into account the information-sharing infrastructure such as credit bureaus that are nowadays present almost in every country.

The adverse selection problem is often tackled through screening procedures implemented by banks. However, the ability and the willingness of banks to screen the potential borrowers may be affected to a large extent by the level of competition in the banking market. The majority of studies examining the impact of competition on bank screening argue for a negative relationship, implying that higher competition leads to less screening by banks, thus 
increasing the probability that a larger share of poor quality borrowers will be granted credit (Manove, Padilla, and Pagano 2001) and (Chan, Greenbaum, and Thakor 1986). By reducing the interest rate spread and, therefore profits, the increase of competition will push banks to cut their screening expenditures and thus perform less screening on loan applicants. In other words, facing stronger competition, banks will ease the acceptance criteria for loan applicants, thus enabling a larger number of them to obtain access to credit. This will enable banks to seize a larger market share while undertaking higher levels of risk.

In order to mitigate the possibility of moral hazard by the borrowers, banks can engage in monitoring the borrowers' activity, aiming at preventing them from conducting "hidden actions". The extent to which banks engage in monitoring activity depends, among others, on the degree of competition in the banking market. The literature on agency problems in the banking industry mainly suggests that monitoring is more likely to take place when banks have market power, whereas, as the competition increases banks tend to reduce their monitoring activity (Caminal and Matutes 2002) and (Covitz and Heitfield 1999). For example, Caminal and Matutes (2002) claim that a monopoly bank has a stronger incentive to monitor, because of the higher proportion of the rents it can appropriate by monitoring.

Another important view to banks' risk-taking is the "risk-shifting" hypothesis of Boyd and de Nicoló (2005), according to which the higher interest rates charged by monopoly banks tend to lead to higher risks, because entrepreneurs will be inclined to engage in riskier projects in order to compensate for the high interest payments. As a consequence, the asset portfolio of the monopoly banks will be characterized by higher level of risks. This implies that the increase of competition in the banking market, which is expected to lower the interest rates, leads to a lower risk in banks' asset portfolios.

Similar to the theoretical studies, the relationship between competition and banks' risk-taking remains ambiguous also in the empirical literature, with one strand claiming that higher competition impairs the stability of the banking system, while the other maintains that the stability of the banking system is enhanced when there is more intense competition between banks. One characteristic of the empirical studies investigating this relationship is that they use different indicators to proxy and measure competition. Also, different indicators are used to measure the level of risk taken by banks. Often, the differences in the empirical results are attributed to the differences in the indicators used to measure competition and the bank's risk.

Keeley (1990) provided empirical support for the "franchise value" hypothesis by investigating the liberalization of legal entry barriers for bank holding companies in the U.S. during the period 1970-1986, which represents a rather indirect measure of banking competition. His findings suggest that banks with higher market power, as expressed by the market-to-book asset ratio (i.e. Tobin's Q), held higher capital-to-asset ratios and lower default risk as expressed by lower risk premiums on uninsured certificates of deposits (for similar studies see also Dick, 2006; Salas and Saurina 2003; Beck, Demirgüç-Kunt, and Levine 2003).

Other studies have used more direct measures of competition such as the Panzar-Rosse $\mathrm{H}$-statistic or market concentration indices and, similarly, the results remain inconclusive with regard to the impact of competition on banks' risk-taking. Using BankScope data for EU-15 countries, Schaeck and Čihák (2007) used separately the $\mathrm{H}$-statistic and the market share of the three largest banks as proxies for competition, while using the equity-to-total assets ratio as a measure of the bank risk. By finding a positive relationship between the $\mathrm{H}$-statistic and the level of bank capitalization, their results suggest that increased competition reduces banks' risk. In addition, they also found that the degree of bank's capitalization is negatively affected by the degree of market concentration (for a similar approach see Boyd, De Nicoló, and Jalal 2006).

A more comprehensive study on the relationship between competition and banking stability has been conducted by Berger, Klapper, and Turk-Ariss (2009) who use three types of measures for banking stability, consisting of a measure of the overall bank risk (i.e. the "Z-score"), a measure of credit risk (i.e. the NPLs) and a measure of the bank's capitalization ratio. Different measures have been used also for market power, including the Lerner Index and market concentration indices. The results of this study suggest that despite increasing the loan risk, market power tends to enhance overall bank stability, thus lending support to the "franchise value" hypothesis.

\section{ESTIMATION OF THE IMPACT OF BANKING SECTOR COMPETITION ON BANKS' RISK-TAKING IN THE CESEE COUNTRIES}

This section presents the empirical estimation of the relationship between banking sector competition and bank's risk-taking in the banking sectors of the CESEE countries during the period 1999-2009. The explanatory variables in our model consist of bank specific variables as well as country-specific macroeconomic 
and institutional variables. The regression is estimated using the following model:

$$
\begin{aligned}
& \text { prov_loans }_{i t}=\alpha_{0}+\beta_{1} H_{-} \text {stat }_{i t}+\beta_{2} \text { non int inc } \_t a_{i t-1}+\beta_{3} \text { equity_ta } a_{i t-1}+\beta_{4} \text { loans }_{-} t a_{i t-1}+ \\
& \beta_{5} \text { nim }_{i t-1}+\beta_{6} \log \text { ta }_{i t}+\beta_{7} \text { growth_loans }_{i t-1}+\beta_{8} \text { rgdpgrowth }_{i t}+\beta_{9} \text { gdp }_{-} \text {percap }_{i t}+\beta_{10} \text { cpi }_{i t}+ \\
& \beta_{11} \log \text { exch_rate }_{i t}+\beta_{12} \text { ebrd_bankref }{ }_{i t}+\beta_{13} \text { propertyrights }_{i t}+\beta_{14} d v_{-} \text {foreign }_{i t}+ \\
& \beta_{15} d v_{-} \text {origin }_{i t}+\beta_{16} d v_{-} \text {year }_{i t}+\beta_{17} d v_{-} \text {country }_{i t}+\varepsilon_{i t}
\end{aligned}
$$

where $i$ denotes the bank and $t$ denotes the year. The description of variables and source of data is presented in the Table 1.

The dependent variable in equation 1 is the loanloss provisions to total loans ratio (prov-loans) which is a proxy for the banks' loan portfolio risk. When a loan becomes non-performing, the bank is required to allocate provisions to cover potential losses from nonperforming loans. Hence, an increase in the loan-loss provisions tends to reflect a deterioration of the loan portfolio quality and subsequently higher bank risk.

Most of the studies investigating the relationship between banking sector competition and risk-taking, by relying on the Structure-Conduct-Performance (SCP) paradigm, use the market concentration indices to control for banking sector competition. However, given that the SCP paradigm has been heavily criticized by other theories such as the efficient structure hypothesis and the contestability theory, which claim that more concentrated markets do not necessarily reveal a higher degree of market power, it may be considered that market concentration may not represent an adequate measure of banking sector competition. Taking into account these criticisms, we consider that inferences on the relationship between competition and risk-taking that have been derived from studies that use the degree of market concentration as a proxy for competition might be questionable. Therefore, in

\begin{tabular}{|c|c|c|}
\hline Variables & Description & Source \\
\hline prov_loans & loan-loss provisions / total loans & BankScope \\
\hline h-stat & Panzar Rosse H-statistic & Authors' calculations \\
\hline nonintinc_ta & total non-interest operating income / total assets & BankScope \\
\hline equity_ta & equity/total assets & BankScope \\
\hline Logta & natural logarithm of total assets & BankScope \\
\hline loans_ta & total loans/total assets & BankScope \\
\hline $\mathrm{Nim}$ & $\begin{array}{l}\text { Net Interest Margin = (interest income - interest expenses)/ } \\
\text { average earning assets }\end{array}$ & BankScope \\
\hline growth_loans & annual growth rate of loans & BankScope \\
\hline Rgdpgrowth & real GDP growth rate & AMECO \\
\hline gdp_percap & gdp per capita & AMECO \\
\hline cpi_ebrd & Inflation & AMECO \\
\hline exch_rate & exchange rate (national currency/Euro) & WIIW \\
\hline ebrd_bankref & EBRD banking reform index & EBRD \\
\hline Propertyrights & Property Rights Index & Heritage Foundation \\
\hline$d v \_$foreign & dummy variable for foreign ownership (1 for foreign ownership) & BankScope \\
\hline$d v \_$origin & $\begin{array}{l}\text { dummy variable for the country-of-origin of the bank (1 for EU- } \\
12 \text { or US) }\end{array}$ & BankScope \\
\hline dv_year & dummy variable for year & - \\
\hline dv_country & dummy variable for country & - \\
\hline
\end{tabular}
our study, banking sector competition is represented by the Panzar-Rosse H-statistic (H_stat1) which, we

Table 1: Description of variables 
have estimated for each country/year. ${ }^{2}$ We acknowledge that the $\mathrm{H}$-statistic is an estimated variable and, therefore, apply the bootstraping technique to correct its standard errors.

The Panzar and Rosse (1987) model directly quantifies the competitive behaviour of firms, by producing the so-called $\mathrm{H}$-statistic, which measures the sum of elasticities of firm's revenues with respect to input prices. The $\mathrm{H}$-statistic indicates how bank's revenues respond to an increase of input prices and takes values from below 0 to 1 . An $\mathrm{H} \leq 0$ implies that banks' competitive behaviour is consistent with monopoly; $0<\mathrm{H}<1$ implies that banks' behaviour is consistent with monopolisitic competition; and $\mathrm{H}=1$ implies perfect competition (for a more detailed explanation of the Panzar-Rosse method see Mustafa and Toçi (2017). By using the Pazar-Rosse H-statistic in estimating the relationship between banking sector competition and risk-taking we have followed a number of authors who have used this variable such as Yeyatti and Micco (2003), Schaeck, Čihák, and Wolfe (2006), Schaeck and Čihák (2007) and Chen (2007). Nevertheless, to the best of our knowledge, no study has previously used the $\mathrm{H}$-statistic as a measure of banking sector competition to examine this relationship for the CESEE countries for the period under investigation.

For comparison purposes, we run a separate model using the Lerner Index (lerner_index variable) as a measure of market power instead of the $\mathrm{H}$-statistic. The Lerner Index is obtained from the study of Efthyvoulou and Yildirim (2014) who have estimated this index for individual CESEE countries for each year in the period 2002-2010. ${ }^{3}$ The Lerner Index is inversely related to the $\mathrm{H}$-statistic, with higher values of the Lerner Index implying higher market power, i.e. lower competition. In addition, also for comparison purposes, we also run a regression that controls for the impact of the Herfindahl-Hirschman Index (hhi_dep) which is a measure of market concentration. The three measures of competition considered in this paper have been used separately in other studies. We use the three of them in this paper. By doing so, we aim at obtaining more reliable inferences on the relationship between banking sector competition and risk-taking, but also provide evidence that can be used to validate the consistency of the three measures of competition.

Apart from the variable of main interest, which is the variable on the banking sector competition, our model includes also other control variables

2 The H-statistic estimates for each sample country and year are available upon request to the authors.

3 The Lerner Index estimates are not available for Estonia and Lithuania. considered to be important for the determination of banks' risk-taking. The control variables included in the model can be classified in three categories: bankspecific variables, macroeconomic variables and institutional variables.

\section{Bank-specific variables}

To control for the potential impact of the diversification of banks' revenues on the quality of loan portfolio we use Lagnonintinc_ta. The risk attitude of a bank considerably depends on the amount of equity held by the bank, which in our regression is represented by Lagequity_ta. Banks that hold higher capital ratios are likely to be more conservative in terms of risk-taking in order to be able to preserve the shareholders equity (Repullo 2004; Hellman, Murdock, and Stiglitz 2000). The extent of loan repayment and, subsequently, the amount of loan-loss provisions, are considered to be affected also by the level of interest rates, which in our regression are represented by the net interest margin (Lagnim). Saunders and Allen (2002) argue that the relationship between high loan interest rates and expected loan repayments is negative, implying that an increase of loan interest rates leads to higher loan-loss provisions. The variable logta represents the natural logarithm of total assets and is included to control for bank size. Larger banks may be considered as safer considering that they might have been operating for a longer period in the market, during which they may have established lending relationships with their clients which, in turn, gives them an advantage in terms of the information they possess. Larger banks are also likely to have stronger financial positions and longer experience in the banking industry, which makes them capable of building more advanced risk management capacities. Among the explanatory variables in our regression we control also for the impact of the annual growth rate of loans (Laggrowth_loans) which is expected to have a positive impact on the loan-loss provisions ratio.

The degree to which banks engage in risk-taking may be well related to whether the bank is domestically owned or foreign owned. According to Dell'Ariccia and Marquez (2004), foreign banks are advantaged in terms of screening technologies to identify the good borrowers by analysing "hard" information. Conversely, domestic banks have the advantage of having additional "soft" information on the borrowers. In this context, Sengupta (2007) claims that foreign banks may end up lending to less risky and larger borrowers, which is also known as "cream-skimming". Given that the foreign banks operating in the CESEE 
region originate from different countries, we consider that the country-of-origin of the banks may also play a role in the way that banks exercise their activity. This implies that their strategy and organizational culture may largely be in line with the standards in their home countries. In this context, Hasselman (2006) has found that the activity of foreign banks in the transition economies is mostly determined by the strategic considerations of the parent banks. Given that the readily available BankScope database provides information only on the current ownership of the bank, we utilize the shareholders' history from this database through which we identify the bank's ownership for the available years. Based on this information, we construct a dummy variable ( $d v \_$foreign) which takes a value of 1 when the bank is more than $51 \%$ foreign-owned and 0 when the bank is domestically owned. To control for the origin of the foreign banks, we construct a dummy variable ( $d v \_$origin) which takes a value of 1 if the foreign bank is an EU-12 or US country and 0 if the bank's origin is some other country.

\section{Macroeconomic variables}

Real GDP growth (rgdpgrowth) proxies the general economic activity or the business cycle is considered to have an important influence on the loan repayment capacity of borrowers. In good times, incomes tend to increase and so does the capacity of the borrowers to repay their loans. The GDP per capita (gdp_percap) is included in the regression to control for the general economic development of each country in the analysis. A higher level of economic development implies a higher level of wealth for its citizens and, thus a higher capacity of loan repayment. Inflation in our regression is represented by the annual growth rate of the Consumer Price Index (cpi_ebrd). Higher inflation reduces real wages when the wages are not adjusted for inflation, thus weakening the loan repayment capacity of the borrowers and leading to higher loan-loss provisions. On the other hand, if loan interest rates are fixed and not adjustable to inflation, then the real interest rate may decline and make it easier for the borrowers to repay their loans when inflation increases. Exchange rate (logexch_rate) is another macroeconomic variable in our regression. The impact of the national currency depreciation on the loan repayment capacity of the borrowers depends on the currency in which loans are denominated. In the CESEE countries the structure of bank loans is dominated by loans denominated in the national currency, while foreign currency deposits represent considerable shares of total deposits in some of the countries, especially in those relying more on remittances and tourism (e.g. Albania, Croatia). Under these conditions, a depreciation of the national currency would increase the loan repayment capacity of the borrowers, thus leading to lower loan-losses.

\section{Institutional indicators}

The banking sector reform process in the transition economies might have influenced also the risk-taking behaviour of the banks. Hence, among the control variables, we include also the EBRD banking reform index (ebrd_bankref), which takes values from 1 to $4+$, with higher values indicating more advanced reform progress. The lack of adequate protection of property rights is often considered to be among the main sources of uncertainty for the banks. To control for the degree of property rights protection, we use the Property Rights Index (propertyrights_hrt) which is provided by the Heritage Foundation. The index takes values from 0 to 100, with higher values showing a better protection of property rights.

Since the banks included in our sample are from different countries, a complete set of country dummies ( $d v \_$country) is included in the model in order to control for unobserved country-specific effects. Our data set includes banks from 15 different countries, where specific country characteristics may have an important role in determining the level of risk taken by banks. To take into account the potential impact from the time-specific effects, the model includes a complete set of year dummy variables ( $d v \_$year).

\section{ESTIMATION METHODOLOGY}

The Hausman test, used to choose between the Random Effects (RE) and Fixed Effects (FE) methods, rejects the null hypothesis that the difference in coefficients is not systematic, hence suggesting that the $\mathrm{RE}$ method is not appropriate to estimate our model. ${ }^{4}$ However, a limitation of FE estimation is that this method does not allow the estimation of the effects of time-invariant explanatory variables and is not efficient in the estimation of slowly-moving variables. In our case, the main limitation of the FE method is the insufficiently efficient estimation of the slowly-moving variables, mainly institutional variables with little within-group variation. In order to estimate the effects of the slowly-moving variables more efficiently and maintain the original features of the FE method, we

\footnotetext{
4 The diagnostic tests are available upon request to the authors.
} 
use the Fixed Effects Vector Decomposition Method (FEVDM), which represents an augmented version of the FE method and takes into account both crossgroup and within-group variation.

The FEVDM approach has been developed by Plümper and Troeger (2004) as a method that enables the estimation of time-invariant variables in the presence of individual fixed effects. In other words, the FEVDM enables the estimation of a fixed effects model that may include also time-invariant explanatory variables. In addition, Plümper and Troeger (2004) claim that the FEVDM is more efficient compared to the FE also in terms of the estimation of explanatory variables that have a low within-group variation. This has been confirmed also by Greene, Orea, and Wall (2010), who found that the use of the FE to estimate models that contain slowly changing variables produces implausible estimates, while the FEVDM estimates are much more meaningful. In our case, the FEVDM estimator enables us to retain the properties of the FE model and at the same time enables us to include the time-invariant variables in our model (i.e. the country dummies) as well as to estimate more efficiently the variables with low within-group variation, which can be referred to also as "rarely changing variables".

The FEVDM is executed through the following steps. In the first stage, the model is estimated using the normal fixed effects model. After the estimation of the regression, we predict the fixed effects vector, which is going to be used in the second stage of the regression. In the second stage, the fixed effects vector is regressed on the time-invariant and the "rarely changing" explanatory variables, which in our case are the country dummies and the variables propertyrights_hrt, dv_origin, and exch_rate. The regression is estimated using OLS. After running the regression, we predict the residuals, which are included among the explanatory variables in the third stage of the FEVDM. In the final stage, the regression is estimated by pooled OLS and includes all the time-variant and time-invariant variables, and also the residuals from the second stage among the explanatory variables.

\section{ESTIMATION RESULTS}

This section presents the estimation results of the determinants of the loan-loss provisions in the CESEE countries during the period 1999-2009. The main variable of interest in this analysis is the $h$ _stat, which measures the impact of banking sector competition on banks' loan-loss provisions. The estimation results are presented in Table 2 which contains the results of four different model specifications.
Our main variable of interest, the $h \_s t a t$, has a negative coefficient that is statistically significant at the $10 \%$ level. The coefficient of -0.096 suggests that an increase of the H-statistic by one standard deviation reduces the loan-loss provisions to total loans ratio by 0.2 percentage points. This suggests that banking sector competition has had a negative impact on the loan-loss provisions ratio, i.e. has contributed to the improvement of the loan-portfolio quality in the banks operating in the CESEE countries.

The negative relationship between competition and bank's risk-taking may primarily be attributed to the fact that with more competition, depositors have more alternatives where to place their deposits and, as a result, they are more likely to "penalize" the excessive risk-taking banks by moving their deposits to safer banks. Based on the discussion from the theoretical background section, this can be the case when assuming that depositors are well informed on the risk behaviour of the bank. However, as earlier explained, it may not always be the case that depositors are well informed on the risk profile of the bank. Nevertheless, depositors may receive signals that may help them better understand the risk behaviour of the bank. Such a signal may be the deposit interest rates offered by a bank. Rapidly increasing deposit interest rates may imply that the bank behaviour is being too aggressive. Under these conditions, continuously increasing deposit rates up to a certain limit may be attractive for the depositors, but excessively high deposit rates may induce banks to engage in high risk - high return projects, which can induce depositors to shift their deposits to safer banks. In other words, "credit rationing" may take place in the deposits market.

An additional explanation as to why the increase of competition may lead to lower risk-taking by banks is related to the negative impact of competition on banks' profits. Bank profits are expected to decline when competition increases, primarily due to the expected decline of interest rate margins. A higher degree of risk-taking by banks, as a response to increased competitive measures, would imply larger potential loan-losses and, as a consequence, higher loan-loss provisions that would further reduce bank profits. Therefore, in order to preserve themselves from a further decline of profits, banks may respond to increased competition by taking measures that improve the risk-management. Examples of these measures may include reviews of the banks' investment strategies as well as the advancement of risk-assessment capacities such as enhancement of screening technologies and investments in personnel training.

Apart from estimating the average impact of competition on loan-loss provisions for the overall sample, 
Table 2: Estimation results (dependent variable: loan-loss provisions/total loans)

\begin{tabular}{|c|c|c|c|c|}
\hline VARIABLES & $\begin{array}{c}\text { (1) } \\
\text { prov_loans }\end{array}$ & $\begin{array}{c}\text { (2) } \\
\text { prov_loans }\end{array}$ & $\begin{array}{c}\text { (3) } \\
\text { prov_loans }\end{array}$ & $\begin{array}{c}\text { (4) } \\
\text { prov_loans }\end{array}$ \\
\hline h_stat & $\begin{array}{l}-0.096^{*} \\
(0.050)\end{array}$ & $\begin{array}{c}-0.183^{* * *} \\
(0.057)\end{array}$ & & \\
\hline hstat_dvnoneu & & $\begin{array}{c}0.501^{* * *} \\
(0.145)\end{array}$ & & \\
\hline lerner_index & & & $\begin{array}{l}0.028^{* *} \\
(0.013)\end{array}$ & \\
\hline hhi_dep & & & & $\begin{array}{c}-0.002^{* * *} \\
(0.001)\end{array}$ \\
\hline Lagnonintinc_ta & $\begin{array}{c}0.016 \\
(0.026)\end{array}$ & $\begin{array}{c}0.016 \\
(0.026)\end{array}$ & $\begin{array}{c}0.009 \\
(0.027)\end{array}$ & $\begin{array}{c}0.033 \\
(0.026)\end{array}$ \\
\hline Lagequity_ta & $\begin{array}{l}-0.011 \\
(0.024)\end{array}$ & $\begin{array}{l}-0.012 \\
(0.024)\end{array}$ & $\begin{array}{l}-0.010 \\
(0.028)\end{array}$ & $\begin{array}{l}-0.005 \\
(0.024)\end{array}$ \\
\hline Lagnim & $\begin{array}{l}-0.076 \\
(0.069)\end{array}$ & $\begin{array}{l}-0.078 \\
(0.069)\end{array}$ & $\begin{array}{l}-0.072 \\
(0.076)\end{array}$ & $\begin{array}{l}-0.124^{*} \\
(0.067)\end{array}$ \\
\hline logta & $\begin{array}{c}-0.720 * * * \\
(0.247)\end{array}$ & $\begin{array}{c}-0.772^{* * *} \\
(0.247)\end{array}$ & $\begin{array}{c}-0.823^{* * *} \\
(0.289)\end{array}$ & $\begin{array}{c}-0.713^{* * *} \\
(0.265)\end{array}$ \\
\hline Laggrowth_loans & $\begin{array}{l}0.004^{* *} \\
(0.002)\end{array}$ & $\begin{array}{l}0.003^{* *} \\
(0.002)\end{array}$ & $\begin{array}{l}0.003^{* *} \\
(0.002)\end{array}$ & $\begin{array}{l}0.003^{* *} \\
(0.002)\end{array}$ \\
\hline rgdpgrowth & $\begin{array}{c}-0.232^{* * *} \\
(0.027)\end{array}$ & $\begin{array}{c}-0.235^{* * *} \\
(0.027)\end{array}$ & $\begin{array}{c}-0.219^{* * *} \\
(0.031)\end{array}$ & $\begin{array}{c}-0.237^{* * *} \\
(0.027)\end{array}$ \\
\hline gdp_percap & $\begin{array}{l}-0.000 \\
(0.000)\end{array}$ & $\begin{array}{l}-0.000 \\
(0.000)\end{array}$ & $\begin{array}{l}-0.000 \\
(0.000)\end{array}$ & $\begin{array}{l}-0.000 \\
(0.000)\end{array}$ \\
\hline cpi_ebrd & $\begin{array}{l}-0.006 \\
(0.043)\end{array}$ & $\begin{array}{l}-0.005 \\
(0.044)\end{array}$ & $\begin{array}{l}-0.021 \\
(0.050)\end{array}$ & $\begin{array}{c}0.040 \\
(0.043)\end{array}$ \\
\hline ebrd_bankref1 & $\begin{array}{l}-0.500 \\
(0.695)\end{array}$ & $\begin{array}{l}-0.802 \\
(0.701)\end{array}$ & $\begin{array}{l}-0.678 \\
(0.914)\end{array}$ & $\begin{array}{l}-0.786 \\
(0.694)\end{array}$ \\
\hline$d v \_$foreign & $\begin{array}{c}0.187 \\
(0.705)\end{array}$ & $\begin{array}{c}0.257 \\
(0.711)\end{array}$ & $\begin{array}{c}0.446 \\
(0.761)\end{array}$ & $\begin{array}{c}0.150 \\
(0.753)\end{array}$ \\
\hline propertyrights_hrt & $\begin{array}{c}-0.059 * * * \\
(0.021)\end{array}$ & $\begin{array}{c}-0.051^{* *} \\
(0.021)\end{array}$ & $\begin{array}{c}-0.062^{* *} \\
(0.025)\end{array}$ & $\begin{array}{c}-0.050^{* *} \\
(0.021)\end{array}$ \\
\hline$d v \_$origin & $\begin{array}{c}0.268 \\
(0.608)\end{array}$ & $\begin{array}{c}0.286 \\
(0.613)\end{array}$ & $\begin{array}{c}0.178 \\
(0.672)\end{array}$ & $\begin{array}{c}0.256 \\
(0.644)\end{array}$ \\
\hline logexch_rate & $\begin{array}{c}-3.864^{* *} \\
(1.530)\end{array}$ & $\begin{array}{c}-3.222^{* *} \\
(1.567)\end{array}$ & $\begin{array}{c}-3.245^{* *} \\
(1.642)\end{array}$ & $\begin{array}{c}-4.878^{* * *} \\
(1.524)\end{array}$ \\
\hline dv_noneu & & $\begin{array}{c}-7.195^{* * *} \\
(2.056)\end{array}$ & & \\
\hline eta & $\begin{array}{c}1.000 \\
(0.000)\end{array}$ & $\begin{array}{c}1.000 \\
(0.000)\end{array}$ & $\begin{array}{c}1.000 \\
(0.000)\end{array}$ & $\begin{array}{c}1.000 \\
(0.000)\end{array}$ \\
\hline Constant & $\begin{array}{c}32.707^{* * *} \\
(8.782)\end{array}$ & $\begin{array}{c}36.824^{* * *} \\
(10.464)\end{array}$ & $\begin{array}{c}31.856^{* * *} \\
(9.449)\end{array}$ & $\begin{array}{c}43.286^{* * *} \\
(8.719)\end{array}$ \\
\hline Observations & 1,497 & 1,497 & 1,385 & 1,527 \\
\hline R-squared & 0.476 & 0.484 & 0.468 & 0.462 \\
\hline
\end{tabular}

Note a): Specification (1) includes the $\mathrm{H}$ _stat as a measure of competition; Specification (2) includes the interaction term between the $\mathrm{H} \_s t a t$ and the dummy variable for the non-EU countries (hstat_dvnoneu); Specification (4) includes the Lerner Index (lerner_index) as a measure of market power; Specification (5) replaces the measures of competition with the degree of market concentration (HHI_dep). 
we run an additional estimation to check whether competition in the non-EU countries of our sample affects bank's risk-taking differently compared to the EU countries of our sample. We do this by interacting our measure of competition ( $h$ _stat) with the dummy variable $d v \_$noneu that takes the value 1 if the country is not an EU member. The interaction term between the $h$ stat and the $d v$ noneu is denoted as hstat $d v n o n e u$. Specification 2 in Table 2 presents the results from the regression that includes the interaction term. According to Brambor, Clark, and Golder (2006), who suggest that the coefficient of one of the constitutive components of the interaction term can be interpreted alone only assuming that the other constitutive term equals zero, the coefficient of the $h \_s t a t$ represents the impact of banking sector competition on banks' risk-taking only in the EU members (i.e. $d v$ noneu=0). The statistically significant negative coefficient of $h$ stat suggests that competition reduces the degree of risk-taking in the EU members of the CESEE region. However, the statistically significant coefficient of the interaction term hstat_dvnoneu shows that in the non-EU countries of the region competition has an additional impact on risk-taking compared to the EU countries of the region. Hence, in order to estimate the impact of banking sector competition on bank's risk-taking in the non-EU countries, we sum up the coefficient of $h$ stat 1 and the coefficient of the interaction term hstat_dvnoneu, which together represent the impact of competition on risk-taking in EU countries plus the additional impact for the non-EU countries. The sum of these two coefficients gives a statistically significant coefficient of 0.318 (Table 3 ) which suggests that, in the non-EU countries of the CESEE region, competition has a positive impact on the degree of banks' risk-taking, i.e. higher competition leads to higher banking sector risks.

The relationship between banking sector competition and risk-taking in the non-EU countries appears to be the opposite of the EU countries where competition appeared to reduce the degree of banks' risktaking. This may reflect deficiencies in other but unobserved factors, given data limitations, which might have affected the relationship between competition and risk-taking in the non-EU members. Such deficiencies may include the quality of the licensing process, which can be affected by the professional capacity of the regulator, but also by potential influences of other factors affecting the licensing process (e.g. political influences). Another important element related to the licensing process is related to the quality of bank applications interested to enter the banking markets. The political instability and the weak rule of law that have characterized most of the non-EU countries of the CESEE during the period under investigation might have discouraged a number of good-quality foreign banks from entering these markets, creating room for competition to be increased through the licensing of weaker banks. Another potential deficiency in the non-EU countries may be related to the quality of personnel available to the banks. The quality of the personnel largely reflects the quality of education that is provided in these countries, which is generally considered to have lagged behind the EU standards.

Apart from Specification 1, in which we estimate the relationship between competition and risk-taking using the $h \_s t a t$ (Panzar-Rosse H-statistic) as a measure of competition, we run also a set of additional regressions as robustness checks to the inferences derived from the Specification 1. In specification 3, we replace the $\mathrm{H}$-statistic with the Lerner Index which is a widely used measure of market power. The estimated coefficient of the Lerner Index is positive and statistically significant at the $5 \%$ confidence level, suggesting that higher market power leads to higher risk-taking by banks. This result confirms our inference on the impact of competition measured by the Panzar-Rosse $\mathrm{H}$-statistic, where we found that higher competition (i.e. lower market power) generally leads to lower risktaking by the banks. In Specification 4, we replace the $\mathrm{H}$-statistic variable with the Herfindahl-Hirschman Index (hhi_dep) which measures the degree of market concentration. The estimated coefficient of the hhi_dep is negative and highly significant, suggesting that higher market concentration is associated with a lower level of risk in the banks' loan portfolios. If the Structure-Conduct-Performance paradigm holds, which claims that a higher degree of market concentration implies a higher degree of market power, then in our case the sign of the market concentration index should have been the same as the sign of the Lerner Index, which measures market power, and opposite to the sign of the $\mathrm{H}$-statistic that measures competition. In our case, the market concentration index has

Table 3: The joint impact of $h \_s t a t$ and hstat_dvnoneu

\begin{tabular}{ccccccc}
\hline prov_loans & Coef. & Std. Err. & $t$ & $P>t$ & [95\% Conf. & Interval] \\
\hline$(1)$ & 0.318 & 0.128 & 2.48 & 0.013 & 0.067 & 0.570 \\
\hline
\end{tabular}


the same sign as the variable measuring competition ( $H_{\text {_stat}}$ ), which suggests that market concentration may not be capturing the impact of competition, but rather some other features of the market. For example, relationship lending is more likely to take place in more concentrated markets and may have an important impact on the risk taken by the banks. In addition, more concentrated banking markets tend to have fewer banks, which makes the bank-supervision process a more straight-forward task (World Bank, 2013). Claiming that market concentration does not appear to capture the impact of banking sector competition may serve as evidence in support to Claessens and Laeven (2004) who claimed that concentration and competition describe different features of a banking market.

Regarding the control variables, as presented in Table 2, the estimation results are quite robust across the different model specifications, so we will focus only in the results from our main model specification (Specification 1). The coefficient of the logta variable, which measures the size of the bank, has a negative and statistically significant coefficient at the $1 \%$ level. This shows that larger banks tend to have a lower level of risk in their loan-portfolio, which does not support the "too big to fail" hypothesis. Instead, it suggests that larger banks tend to be safer, which may reflect their advantages in having borrower-specific information, assuming that they have been operating for a longer period in the market, as well as their superior riskmanagement capacities stemming from their supposedly stronger financial position. Another bank-specific variable that has resulted statistically significant is the annual growth rate of loans (Laggrowth_loans). Higher credit growth rates appear to have led to higher risktaking. A rapid expansion of loans is likely to be based on lax lending criteria. In order to increase their market shares, banks may choose to deviate from appropriate screening, thus enabling low-quality borrowers to gain access to credit. The other bank-specific variables, Lagnonintinc_ta, equity_ta and nim, have the expected signs, but do not have a statistically significant impact on the quality of the loan portfolio.

Regarding the country-level indicators, our results show that real GDP growth rate (rgdpgrowth) has a negative coefficient, which is statistically significant at the $1 \%$ level. This implies that higher GDP growth rates tend to significantly reduce the level of risk in the banks' portfolios, presumably by enhancing the repayment capacity of the borrowers. However, the negative impact of the real GDP growth rate on the loan-loss provisions ratio may also reflect the fact that during good times for the economy banks are more optimistic for the future, so they may tend to allocate less loan-loss provisions to cover potential loan losses. The exchange rate (logexch_rate), has a statistically significant negative coefficient. This suggests that the depreciation of the national currency improved the loan-repayment capacity of the borrowers, which may reflect the fact that the loan structure in most of the CESEE countries is composed of loans denominated in national currency, while foreign currency savings represent substantial part of deposits in some of the countries. Under such conditions, the depreciation of the national currency eases the loan repayment for the foreign currency deposit-holders. The other macroeconomic variables included in our regression, which are the GDP per capita (gdp_percap) and the inflation rate (cpi_ebrd), have a statistically insignificant impact on the determination of bank risk-taking in the CESEE countries.

The coefficient on the property rights index (propertyrights) is negative and statistically significant. A better protection of property rights, which is primarily related to a more efficient judicial system, appears to significantly reduce the level of risk in the bank loan portfolios. In countries with a better protection of property rights, the repayment of loans is better enforced. In addition, by being aware of the efficient judicial system, the borrowers will ex-ante be more disciplined in terms of the timely repayment of their loans. The other institutional variable, ebrd_bankref, has a statistically insignificant coefficient. Even though the banking reform process is considered to have been one of the key factors that improved the stability of the banking system in the transition economies, the insignificant coefficient in our regression may reflect the fact that the main effects from the banking reform were achieved at the beginning of the transition process. Whereas, during the period 1999-2009, which is covered in our analysis, the banking reform index is shown to have been quite static or slowly-moving from year to year. The dummy variables on foreign ownership ( $d v \_$foreign) and country-of-origin ( $d v \_o r i-$ gin) likewise appear to have insignificant coefficients.

\section{CONCLUSIONS}

The theoretical and empirical literature on the relationship between banking sector competition and risk-taking remains largely inconclusive with regard to the nature of this relationship. This paper estimates empirically the impact of banking sector competition and banks' risk taking in the CESEE countries during the period 1999-2009. In order to use a direct measure of banking sector competition, we estimated the Panzar-Rosse $\mathrm{H}$-statistic for each country and for each 
year, while the measure of bank risk consists of the ratio of loan-loss provisions to total loans. To our knowledge, this is the first study to use the Panzar-Rosse $\mathrm{H}$-statistic to measure the impact of banking sector competition on risk-taking for transition economies of CESEE. Estimation is conducted using the Fixed Effects Vector Decomposition Method.

The estimation results suggest that banking sector competition has had a negative impact on the loan-loss provisions ratio implying that, on average, competition contributed to the improvement of the loan-portfolio quality in the CESEE countries during the period 1999-2009. However, the results differ significantly when distinguishing between the EU and non-EU countries of the CESEE region. While for the EU countries the relationship between banking sector competition and risk-taking remains negative, this relationship is positive for the non-EU countries of the region, suggesting that an increase of competition in the non-EU countries may be detrimental for the stability of the banking sector in these countries. This result may be reflecting potential unobserved deficiencies in the non-EU countries, such as the quality of the financial institutions licensing process and the quality of personnel available to banks, which might have influenced the relationship between competition and risk-taking in the banking sectors of these countries.

For comparison, we have estimated the PanzarRosse $\mathrm{H}$-statistic also using the total income as the dependent variable (in addition to the $\mathrm{H}$-statistic that was estimated with interest income as dependent variable), and the results with respect to the impact of competition on risk-taking remain similar. In addition, the results remain similar also when replacing the $\mathrm{H}$-statistic with the Lerner Index, which is an alternative measure of market power. The coefficient on the Lerner Index resulted significantly positive, suggesting that market power increases the degree of risk-taking, thus confirming our results on the negative relationship between competition and risk-taking. Another alternative measure used in our regression consists of the market concentration index, which resulted in a significantly negative coefficient, suggesting that banks operating in more concentrated markets tend to undertake lower risks. This result implies that market concentration has a similar impact to competition, which is in contradiction to the SCP paradigm that views concentration as an inverse measure of competition. This finding might serve as evidence in favour of the view that competition and concentration measure different features of the market.

Regarding the impact of the other control variables that are included in the regression, the results suggest that bank size is negatively related to the bank's risk-taking, while the higher growth rate of loans tends to lead to higher risk-taking. The overall performance of the economy seems to be highly important for the quality of the loan portfolio. Higher real GDP growth rates appear to improve the quality of loans. The loan-portfolio quality appeared to have been significantly enhanced also from the national currency depreciation. Another factor that appears to have had a highly significant impact on the enhancement of loan-portfolio quality is the protection of property rights. In general, the results suggest that the quality of the banks' loan portfolios is mostly determined by factors related to the operating environment, which may be exogenous to banks' actions.

\section{REFERENCES}

Beck, T., Demirgüç-Kunt, A., and Levine, R. 2003. Bank Concentration and Crises. National Bureau of Economic Research Working Paper Series, Working Paper No. 9921.

Berger, A., Klapper, L., and Turk-Ariss, R. 2009. Bank Competition and Financial Stability. World Bank, Policy Research Working Paper No. 4696.

Boyd, J., De Nicoló, G., and Jalal, A. 2006. Bank Risk-Taking and Competition Revisited: New Theory and New Evidence. IMF Working Paper No. WP/06/297.

Brambor, T., Clark, W., and Golder, M. 2006. Understanding Interaction Models: Improving Empirical Analyses. Political Analysis 14 (1): 63-82.

Chan, Y., Greenbaum, S. and Thakor, A. 1986. Information Reusability, Competition and Bank Asset Quality. Journal of Banking and Finance 10 (2): 243-253.

Chen, X. 2007. Banking Deregulation and Credit Risk: Evidence from the EU. Journal of Financial Stability 2 (4): 356-390.

Claessens, S. and Laeven, L. 2004. What Drives Bank Competition? Some International Evidence. Journal of Money, Credit, and Banking 36 (3): 563-583.

Covitz, D. and Heitfield, E. 1999. Monitoring, Moral Hazard, and Market Power: A Model of Bank Lending. Board of Governors of the Federal Reserve System (U.S.), Finance and Economics Discussion Series No. 1999-37.

Dell'Ariccia, G. 2000. Learning by Lending, Competition, and Screening Incentives in the Banking Industry. University of Pennsylvania, Canter for Financial Institutions Working Papers No. 00-10.

Demsetz, R., Saidenberg, M., and Strahan, P. 1996. Banks with Something to Lose: The Disciplinary Role of Franchise Value. Economic Policy Review 2 (2): 1-14.

Dick, A. 2006. Nationwide Branching and Its Impact on Market Structure, Quality, and Bank Performance. Journal of Business 79 (2): 567-592. 
Efthyvoulou, G. and Yildirim, C. 2014. Market Power in CEE Banking Sectors and the Impact of the Global Financial Crisis. Journal of Banking and Finance 40 (C): 11-27.

European Bank for Reconstruction and Development 2001. Transition Report. London.

Greene, W., Orea, L., and Wall, A. 2010. Stochastic Frontiers using a Fixed-Effect Vector Decomposition Approach with an Application to ICT and Regional Productivity in Spain. Universidad de Oviedo, Departamento de Economía, Efficiency Series Paper 4/2010.

Haselmann, R. 2006. Strategies of Foreign Banks in Transition Economies. Emerging Markets Review 7 (4): 283-299.

Hellman, T., Murdock, K., and Stiglitz, J. 2000. Liberalization, Moral Hazard in Banking, and Prudential Regulation: Are Capital Requirements Enough? American Economic Review 90 (1): 147-165.

Keeley, M. 1990. Deposit Insurance, Risk, and Market Power in Banking. The American Economic Review 80 (5): 1183-1200.

Koskela, E. and Stanbecka, R. 2000. Is there a Trade-Off between Bank Competition and Financial Fragility? Journal of Banking and Finance 24 (12): 1853-1873.

Manove, M., Padilla, A., and Pagano, M. 2001. Collateral versus Project Screening: A Model of Lazy Banks. Journal of Economics 32 (4): 726-744.

Marquez, R. 2002. Competition, Adverse Selection, and Information Dispersion in the Banking Industry. The Review of Financial Studies 15 (3): 901-926.

Mustafa, A. and Toçi, V. 2017. Estimation of the Banking Sector Competition in the CEE Countries: The PanzarRosse Approach. Proceedings of Rijeka Faculty of Economics: Journal of Economics and Business 35 (2): 459-485.
Panzar, C. and Rosse, J. 1987. Testing for 'Monopoly' Equilibrium. Journal of Industrial Economics 35 (4): 443-456.

Plümper, Th. and Troeger, V. 2004. The Estimation of TimeInvariant Variables in Panel Analyses with Unit Fixed Effects. SSRN Electronic Journal. (https://papers.ssrn. com/sol3/papers.cfm?abstract id $=565904$ ) (accessed September 7, 2017).

Repullo, R. 2004. Capital Requirements, Market Power, and Risk-Taking in Banking. Journal of Financial Intermediation 13 (2): 156-182.

Salas, V. and Saurina, J. 2003. Deregulation, Market Power and Risk Behaviour in Spanish Banks. European Economic Review 47 (6): 1061-1075.

Saunders A. and Allen, L. 2002. Credit Risk Measurement. John Wiley \& Sons, Inc. New York.

Schaeck, K., Čihák, M., and Wolfe, S. 2006. Are more Competitive Banking Systems more Stable? IMF Working Paper No. WP/06/143.

Schaeck, K. and Čihák, M. 2007. Banking Competition and Capital Ratios. IMF Working Paper No. WP/07/216.

Sengupta, R. 2007. Foreign Entry and Bank Competition. Journal of Financial Economics 84 (2): 502-528.

Stiglitz, J. and Weiss, A. 1981. Credit Rationing in Markets with Imperfect Information. American Economic Review 71 (3): 393-410.

World Bank 2013. The Role of the State in Promoting Bank Competition. Presented in Global Financial Development Report 2013. The World Bank, Washington, D.C.

Yeyatti, E. and Micco, A. 2007. Concentration and Foreign Penetration in Latin American Banking Sectors: Impact on Competition and Risk. Journal of Banking and Finance 31 (6): 1633-1647. 